\title{
Making Videos as Assessment Tasks in Japanese Senior High School
}

\section{Yoshimi Ochiai \\ Ritsumeikan University}

\section{Reference Data:}

Ochiai, Y. (2019). Making videos as assessment tasks in Japanese senior high school. In P. Clements, A. Krause, \& P. Bennett (Eds.), Diversity and inclusion. Tokyo: JALT.

Task-based language teaching (TBLT) is one of the mainstream pedagogical approaches in the TESOL field (Miyasako, 2012), but TBLT is not a popular pedagogy in the Japanese senior high school (SHS) context. However, it is sometimes necessary for teachers to complement the contents of the textbook to make lessons more communicative and authentic. Willis's (2016) TBLT framework was used to design lessons in an elective English Conversation class with 13 SHS students majoring in agriculture. An example task is described in which students recorded introduction videos of their unique school facilities and these were then used for the students presentation tests. Their performance tests became more authentic and most students were motivated to complete the task. It is suggested that TBLT could be a good method to supplement the textbook in SHS in Japan.

タスクを用いた教授法(以下、TBLT) は、英語教授法の分野において主要な一教授法である(Miyasako，2012)が、日本の高 等学校教育現場では、TBLTはあまり用いられていない。一方教員は、授業をよりコミユニカテイブで真正性を高めるために、教 科書内容を補完する必要性に迫られることがある。そこで、13名の農業高校生の受講する選択英語会話の授業にWillis (2016 ) の提唱するTBLTの枠組みを取り入れた。学校特有の施設紹介を動画撮影することをタスクとして課し、生徒の発表テストと した。そうすることで、パフォーマンステストの真正性が増し、大半の生徒はタスクを遂行しようとする意欲が高まった。本稿 は、TBLTは教科書内容を補填するためには良い方法であると提唱する。

n 2013, the Japanese Ministry of Education, Culture, Sports, Science and Technology (MEXT, 2014) released an English education reform plan to nurture students' English communication skills. Since then, a full-scale development of English education has started (Tada, 2016), and junior and senior high school (SHS) English teachers in Japan have started to incorporate ideas for how students should use English into their English classes. If teachers emphasize student output in their lessons, task-based language teaching (TBLT) is one of the mainstream pedagogical approaches in the field of teaching English to speakers of other languages (Miyasako, 2012) for encouraging students to do something in English. TBLT constitutes a strong version of communicative language teaching because tasks function as useful devices for planning a communicative curriculum in contexts where there are few opportunities for more authentic communicative experiences (Ellis, 2003). However, in Japan, where English is taught as a foreign language, TBLT has not been a popular approach among SHS English teachers.

This paper begins with a discussion of how TBLT is viewed in Japanese SHS contexts and reasons for incorporating mobile devices into lesson plans. Then the decision to introduce TBLT into a SHS context is explained as well as the design of lesson plans based on TBLT. An example task is described in which students were assigned to record videos introducing school facilities with mobile devices.

Use of Task-Based Language Teaching in the Japanese Senior High School Context

Japanese English educators have begun seeking ways to improve their students' communicative competence, including the introduction of tasks (Takizawa, 2010).

The emphasis on meaning and authenticity in TBLT appeals to high school teachers (Akaike, 2015). However, there have been some criticisms of TBLT in the Japanese high school context, especially from advocates of the presentation, practice, and production (PPP) model. Takizawa (2010) and Miyasako (2012) claimed that learners do not have enough language proficiency to perform tasks. TBLT has not yet become a pervasive concept among English high school educators in Japan because the word task is not in ministry curricular guidelines (Akaike, 2015). Aragane (2014) pointed out that most of the activities in authorized high school textbooks included less creative communication activities, such as pair dialogue practice, and only a few tasks were provided. 
Samuda and Bygate (2008) distinguished three taxonomies in the design of a task: task-supported, task-referenced, and task-based approach. In task-supported language teaching (TSLT), tasks are designed to support a specific structural or lexical item (Robinson, 2011). As the authorized textbook is the main component of the language curriculum design, TSLT tends to be considered the most feasible pedagogy within the Japanese teaching context (Aragane, 2014; Takizawa, 2010;). This is because the ministry curriculum guidelines and textbooks form a structural syllabus, designed principally for teaching grammar expressively (Aragane, 2014; Miyasako, 2012). However, the materials in textbooks sometimes do not match students' actual situation and interests, so teachers need to prepare original materials to raise students' motivation and interest. Thus, the aim of the action research reported here was to introduce TBLT into lesson plans to challenge those criticisms by showing how it can be used to complement the content of the textbook.

\section{Smartphones as Accessible ICT Devices for High School Students}

Stockwell and Hubbard (2013) stated that learners are likely to engage with a task that is close to existing uses in the field of mobile-assisted language learning. According to the Japanese government's Cabinet Office (2018), 95\% of high school students own smartphones, which is a handy information communication technology (ICT) device for them to use. High school students also enjoy watching and making short videos. In a survey of 596 junior and SHS girls, Pre Teens Labo (2018) found that more than $90 \%$ have used free video on-demand services including YouTube, and about $60 \%$ of female SHS students have uploaded their own videos on social media. Using smartphones to watch and make videos is students' normal practice, so they are likely to react positively towards working on the task of recording a school introduction video. In TBLT, language is viewed as a tool for communicating and doing things (Larsen-Freeman \& Anderson, 2011), and having students use ICT devices in TBLT syllabi may help them improve their meaning-making abilities in the foreign language.

\section{Teaching Context}

This study was conducted in an elective course titled English Conversation for agricultural majors at a public SHS in the northern Kanto region of Japan. As this was an elective course, the class consisted of 13 third-year students, two of whom held Eiken 3rd level or A1 in CEFR. The other students' English level was low beginner. Most of the elective classes in this school are related to various agricultural subjects, and few students choose the elective English class. Therefore, the students in this class generally liked studying English.
For this course, the students used the textbook Hello There! (Sakai et al., 2017, Tokyo Shoseki). It was designed for 1st-year students in SHS, so some modification of the textbook's contents was required for these 3rd-year students. The task described here was implemented during a unit called "My Interests." The theme of the unit was about sharing hobbies and favorite activities. As a final exercise, the textbook recommends that students give a short speech to present their favorite things. The students had already spent a year together before this conversation class, and they had a general idea of what their peers liked and disliked doing in their free time. Therefore, the suggested activity was not seen to be particularly useful for this group of students.

Even though the students knew each other, they did not know what their classmates studied as their individual majors. As the school offered different agriculture major courses (e.g., biotechnology, bioproduction, and food sciences), there were separate facilities and laboratories to learn about the specific agricultural fields for their courses in the school. The students seldom stopped by the laboratories of different majors so had some knowledge gaps about the school curriculum. The uniqueness of the school facilities could be great realia for introducing what students were learning not only to their peers but also to other people outside this school.

\section{The Task}

As there is flexibility in TBLT design, there are various definitions of what constitutes a task. In this study, the pedagogical approach followed Willis's (2016) overview of a taskbased framework for language teaching. Willis (2016) recommended that TBLT should be composed of three prominent parts: pretask, task cycle, and language focus. The primary taxonomy of a task's characteristics can be categorized into two dimensions: grammar focused or grammar unfocused. In this unit, the unfocused task, which is designed to provide learners with general communication opportunities (Larsen-Freeman \& Anderson, 2011), was introduced to match the theme in the authorized textbook with the students' interests.

\section{Pretask: Introduction to Topic and Task}

As a warm-up activity for the lesson, students played a guessing game. In pairs, one student looked at a picture of a room in the school, which was projected on a blackboard. After a few seconds, when the display was turned off, the student explained the room to his/her partner in English. The partner guessed which room his or her partner was describing. Students enjoyed a few rounds with different rooms. Then pairs switched 
roles and repeated the activity. After this warm-up activity, a word list of schoolrooms was introduced. The students practiced the vocabulary and pronunciation by reading aloud.

\section{Task Cycle: Task}

The students' learning target for this unit was producing a video to introduce school facilities. To model the task, I showed a self-recorded video introducing the teachers room to the students. The task for the students was to choose a place at school and make a video with their smartphones to present to a visitor. One student didn't have a smartphone, so was lent an iPad. First, the students brainstormed a list of facilities unique to their school, and each student chose a different place. Then, the students brainstormed how they would introduce their chosen places.

\section{Task Cycle: Planning}

Students worked in groups of three, and each student wrote a script introducing their chosen facility, with advice from the other group members. Only after the members finished writing their scripts and had received the teacher's feedback could the group move on to shooting a video. Each group member needed to support the other group members in the planning stage through informal peer review. I corrected the scripts directly so as to make the contents of the speeches understandable to others and gave some advice orally to the individual students about how to enrich their introduction videos.

During this planning stage, I negotiated with the teachers who oversaw the facilities the students had chosen for their video shoots. The students also consulted those teachers to get permission to shoot videos a week before the actual filming day. As Harada (2017) stated, informal groundwork among colleagues before proposing a plan officially is considered customary to encourage a school reform plan to be smoothly accepted by decision-makers in Japanese schools. Thus, this kind of groundwork is fundamental to making projects successful in a Japanese high school context.

\section{Task Cycle: Planning}

Students recorded their videos during one class period. I made two rules for the video recording activity: (a) group members needed to support and collaborate with each other, and (b) they had to come back to the classroom before the class hour ended. I also offered flexibility: (a) students were allowed to record only the location if they did not want to show their faces on their videos, and (b) students could create the movies as a group or individual work. Students visited the filming locations where they were going to make videos for their school introductions with their group members. One group decided that all group members would appear in each selfie-video. Two students made selfie-videos and one shot a video of the location. The other students decided to divide their group into roles: a reporter, a video-taker, and a director. I went to the locations and monitored the students. After recording their videos, students went back to the classroom and sent their videos to the teacher via Airdrop or email using the tethering function on the teacher's personal smartphone.

\section{Task Cycle: Report}

A week after filming, all the videos were shown to the class. Most of the students commented on the skills of selfie-video recording. The creators of each video reacted spontaneously and made as many comments as they could in English, and those comments were about a few English words. Later, they made comments in Japanese regarding where they had made the most effort and how they had tried to entertain viewers during filming. The students evaluated each other's videos using the rubric provided (see Appendix A) as a peer review activity.

\section{Language Focus: Analysis}

While I was watching the students' videos for the first time in class, I noticed that they chose the words "best," "favorite," "number one" and "like" as interchangeable words. Some of the incorrect sentences students generated included (a) My like teacher is Mr. Muraoka. (b) I best food processing class number one.

After sharing the videos and students' comments, I wrote some incorrect sentences on the blackboard and asked the whole class which part of the sentences was wrong. The students were initially silent, so I prompted them by asking how they could use "best," "favorite," "number one" and "like" in Japanese. They finally noticed their mistakes and uttered their thoughts about the corrected sentences.

\section{Language Focus: Practice}

After checking the lexical mistakes, individual students created sentences using the target vocabulary from the previous activity. Finally, they wrote a short essay (over 40 words) about their favorite rooms at home to further practice the target vocabulary. Students wrote the essay following a basic paragraph writing structure that they had previously learned in the course. 


\section{Assessment}

This project was assessed in two different ways: a performance-based assessment and a midterm test. For the performance-based assessment, both formative and summative assessments were conducted.

\section{Performance-Based Assessment}

As the aim of formative assessment is for teachers to provide students with ongoing feedback about their learning progress, formative assessment during the selfie-video project was conducted as follows: (a) feedback on scripts for the project; (b) monitoring students' filming; (c) indicating lexical and grammatical mistakes after watching the students' videos; and (d) checking target grammar and vocabulary in students' short essays about their favorite rooms in their houses. For the summative assessment, a simple rubric was introduced to assess the students' videos (see Appendix A). In this rubric, the maximum score for the final product was 15 points. Three elementscontent, entertainment value, and comprehensibility - were assessed using three scoring scales. As the focus of this task was authentic communication, grammatical accuracy was not included in the rubric.

\section{Midterm Test}

A written instructional achievement test is commonly used to assess students' learning in a high school context. In addition to performance-based tests, a midterm test was used to evaluate students' achievements. As the midterm test was based on three units of study, about one third of the total points in the test were designated to measure student achievement on this unit. Reading and writing were tested, and 15 points were distributed to each section.

For the reading comprehension question, students read a teacher-prepared presentation about a favorite place, which was written in a style similar to students' videos and used similar lexical and grammatical items, and then answered five multiplechoice questions about it.

For the writing section, students wrote a short essay that was set at 40 words about their favorite places in their school. The rubric for assessing students' writing competence is shown in Appendix B. The focus was on students' written fluency and communicative competence. Thus, less importance was placed on students' grammatical accuracy.

\section{Discussion}

After conducting this project, reflective analysis brought up several elements to consider for future lesson modification. The following sections explain the benefits and difficulties of having conducted this video project in a public high school context.

Willis (2016) noted that success in achieving the goals of a task naturally helps enhance students' motivation. In addition, Evans and Boucher (2015) suggested that students must be given opportunities to experience autonomy to enhance their intrinsic motivation to engage in a learning activity. Offering the students choices for where to shoot and how to film supported the students' engagement with the task. The selfdetermination process used to complete this task may have brought a sense of autonomy to the students.

When the task was completed, each student's opinions about the task were collected through informal interviews. Twelve of them expressed positive reactions to this task, and one student said that she enjoyed the class because she could do different things that she could not do in the other English course. However, one student said he didn't like the task much because he preferred to stay in the classroom and study at his desk. In addition, before the recording, he shared his concerns about standing out in a video. Providing the choice of not showing their faces on the video enabled all students to complete the task successfully. This attempt to accommodate individual learners' needs is recommended in universal design for learning (Evans \& Boucher, 2015) to create an inclusive environment.

At the end of the year, a course evaluation survey was conducted. In the section asking about the favorite activity in this course throughout the year, one student wrote, "A selfie-taking activity was my favorite activity of all, but I hoped that I could share my video with foreign people." As discussed above, most students were motivated to present their video projects as part of the TBLT curriculum. If it had been possible to share the video with people living in foreign countries, as the student mentioned in the questionnaire, the students would have been even more motivated.

However, the plan to share the videos with people outside the school could not be brought about for several reasons. MEXT announced that they would deregulate their notice issued in 2009 that prohibited elementary and junior high school students from bringing their smartphones to school ("Education Ministry to Review Smartphone Ban," 2019). This has provoked debate among Japanese secondary educators over students' smartphone usage. Regrettably, the number of social networking service (SNS) crimes involving juvenile victims has more than doubled in a decade, and in 2017, 1,813 child 
victims under 18 suffered through SNSs because of obscene acts committed by adults through child pornography (National Police Agency of Japan, 2018).

The school where this study was conducted counseled students regarding these issues. Notwithstanding, during the semester in which this project was implemented, some students were victims of abuse via social media and teachers in the school provided counseling to help them recover from the resulting trauma. As a result, most of the teachers had developed a negative impression of online media. The initial plan was to share the students' videos with foreign English learners via online storage; as time went by, however, the school became busy counseling those students, and the idea of exchanging videos could not be realized.

\section{Limitations}

It was not possible to ask a third party to assist in grading the students' videos, so the students' videos were graded only by the teacher. As I already knew the school facilities, even though there were many language-related mistakes in the videos, my background knowledge of the schoolrooms made it easy to understand what students wanted to say about the facilities. Showing the students' final products to a third person with no knowledge of the students or the school could be an effective way to evaluate the students' videos more objectively. However, the use of the rubric (see Appendix A) helped to keep the evaluation consistent across all students within the class.

In this task, two kinds of peer review activities were introduced. One was informalat the planning stage when students made scripts in groups; the other was formal-in the language-focused phase at the video-sharing party, using the rubric provided (see Appendix A) and correcting lexical mistakes. In the later peer review activity, when the students tried to find the lexical mistakes in their peers' videos, they seemed to have difficulties identifying mistakes by themselves. This activity could have been scaffolded if I had watched the videos before class and identified a specific lexical or grammatical feature for students to analyze as they watched the videos. If I had given students some hints about lexical mistakes, they might have been able to pick them out by themselves.

This difficulty was similar to Kaneko's (2011) finding that Japanese students with lower English proficiency couldn't comment on grammatical problems by themselves in a peer editing session. Colpitts (2016) mentioned that giving and receiving feedback from peers helped students to analyze the area to work with, but in the current project, the students' perception of lacking the English ability to edit their peers' work may have negatively affected their attitude towards feedback because they weren't sure their edits were correct. To raise students' awareness in the language-focused phase of TBLT and engage students in editorial activity with confidence, teachers may need to choose some grammatical or lexical points that the students should pay attention to prior to their peer feedback. Collecting more student feedback on the task would also be useful to provide complementary support to the students' learning and to create implications for future tasks.

\section{Conclusion}

This video project proved an appropriate implementation of TBLT for these SHS students. They have easy access to social media and are used to watching and taking videos in their daily lives. Making short movies as a language class task motivated the students to use English because it provided a clear goal in using the target language and engaged the students, who all successfully completed the task. Well-planned, language-focused peer-evaluation activities, such as focusing on a grammatical point, could enhance students' language awareness, especially for students with low English competency (Kaneko, 2011).

There is skepticism in Japan about the effectiveness of TBLT (Sato, 2010), and some researchers have claimed that PPP or TSLT fits better in a Japanese SHS context (Aragane, 2014; Hayashi, 2017; Takizawa, 2010). However, this study indicates TBLT can be a good way to supplement the textbook and provide an opportunity for learning that is personalized to the students' lives and interests.

\section{Bio Data}

Ochiai Yoshimi is currently an English teacher at Ritsumeikan University in Shiga, Japan, but she has devoted most of her teaching career to teaching junior and senior high school students. At Gunma Prefectural Oizumi High School, she implemented various communicative English activities to motivate her students. <ochiai-y@fc.ritsumei.ac.jp>

\section{References}

Akaike, H. (2015). How to implement tasks in junior and high school English classes. The Chubu English Language Education Society, 44, 211-216. https://doi.org/10.20713/celes.44.0_211

Aragane, F. (2014). Analyzing oral activities and tasks in Japanese senior high school textbooks. Bulletin of Education and Health Sciences, Uekusa Gakuen University, 6, 99-107. https://doi. org/10.24683/uekusad.6.0_99 
Cabinet Office, Government of Japan. (2018, February). 平成29年度青少年のインターネット利用環境 実態調査 調査結果 (速報) [Results of a survey about the Internet usage rate among juveniles in 2017 (breaking news)]. Retrieved September 19, 2018, from http://www8.cao.go.jp/youth/youth-harm/ chousa/h29/net-jittai/pdf/sokuhou.pdf

Colpitts, B. D. F. (2016). Japanese students' perceptions of peer corrective feedback in an EFL classroom. Acta Humanistica et Scientifica Universitatis Sangio Kyotiensis, 49, 345-358

Education ministry to review smartphone ban for elementary and junior high school students. (2019, Feb. 20). The Japan Times. Retrieved from https://www.japantimes.co.jp/

Ellis, R. (2003). Task-based language learning and teaching. Oxford, England: Oxford University Press.

Evans, M., \& Boucher, A. R. (2015). Optimizing the power of choice: Supporting student autonomy to foster motivation and engagement in learning. Mind, Brain, and Education, 9(2), 87-91. https:// doi.org/10.1111/mbe.12073

Harada, T. (2017). Groundwork laid unobtrusively in advance to pass a school reform plan: With a focus on self-presentation. Journal of East Asian Studies, 15, 15-29.

Hayashi, N. (2017). The methods and teaching technique which are suitable to Japanese EFL Learners: PCPP, AL and materials. Bulletin of Miyazaki Municipal University Faculty of Humanities, 24(1), 155-171.

Kaneko, T. (2011). Japanese college students' perceptions of peer editing activities. In A. Stewart (Ed.), JALT2010 Conference Proceedings (pp. 378-386). Tokyo: JALT. Retrieved from http://jaltpublications.org/sites/default/files/pdf-article/jalt2010proc-38.pdf

Larsen-Freeman, D., \& Anderson, M. (2011). Techniques and principles in language teaching (3rd ed.). New York, NY: Oxford University Press.

MEXT. (2014). English education reform plan corresponding to globalization. Retrieved March 12, 2019, from http://www.mext.go.jp/en/news/topics/detail/__icsFiles/ afieldfile/2014/01/23/1343591_1.pdf

Miyasako, N. (2012). How can classes be transformed into real communication scenes? The Bulletin of Japanese Curriculum Research and Development, 35(1), 41-55. https://doi.org/10.18993/ jcrdajp.35.1_41

National Police Agency of Japan. (2018). 平成29年におけるSNS等に起因する被害児童の現状と対策につ いて [Current situation and measure for the child victim caused by SNS in 2017] [Data file]. Retrieved December 20, 2018, from https://www.npa.go.jp/safetylife/syonen/H29_sns_shiryo.pdf

Pre Teens Labo. (2018, May 22). 女子中高生と動画サービスに関する調査 [Study of the relationships between video sharing services and junior and senior high school girls]. Retrieved July 19, 2018, from https://lab.prcm.jp/online-movie/
Robinson, P. (2011). Task-based language learning: A review of issues. Task-based Language Learning, 61(1), 1-36. https://doi.org/10.1111/j.1467-9922.2011.00641.x

Samuda, V., \& Bygate, M. (2008). Tasks in second language learning. London, England: Palgrave Macmillan.

Sato, R. (2010). Reconsidering the effectiveness and suitability of PPP and TBLT in the Japanese EFL classroom. JALT Journal, 32(2), 189-200. Retrieved from https://jalt-publications.org/sites/ default/files/pdf-article/perspectives.pdf

Stockwell, G., \& Hubbard, P. (2013). Some emerging principles for mobile-assisted language learning. Monterey, CA: The International Research Foundation for English Language Education.

Retrieved from http://www.tirfonline.org/english-in-the-workforce/mobile-assisted-languagelearning

Tada, M. (2016). Recent reform to the English education system in Japan. 21st Century Education Forum, 11, 21-29.

Takizawa, K. (2010). Using tasks in the English classroom. Hakuoh Journal of the Faculty of Education, 4(1), 277-296.

Willis, J. (2016). A framework for task-based learning [Flexitome e-book]. Retrieved from http:// flexitome.com/book/443\#

Appendix A

School Introduction Selfie-Video Rubric

\begin{tabular}{|c|c|c|c|}
\hline Score & Content of the video & $\begin{array}{l}\text { Entertainment value and } \\
\text { appeal to the audience }\end{array}$ & $\begin{array}{l}\text { Comprehensibility of } \\
\text { the video }\end{array}$ \\
\hline 5 & $\begin{array}{l}\text { Informative, clear, and } \\
\text { easy to understand the } \\
\text { places }\end{array}$ & $\begin{array}{l}\text { Reporters are talking to } \\
\text { the audience, so easy to } \\
\text { engage with the video }\end{array}$ & $\begin{array}{l}\text { Clear and } \\
\text { understandable; } \\
\text { voice was loud enough } \\
\text { to listen to }\end{array}$ \\
\hline 3 & $\begin{array}{l}\text { Not enough information } \\
\text { to understand the places }\end{array}$ & $\begin{array}{l}\text { Some parts of the video } \\
\text { were fun to watch }\end{array}$ & Mostly understandable \\
\hline 1 & $\begin{array}{l}\text { Listeners had too } \\
\text { many difficulties with } \\
\text { understanding the places }\end{array}$ & $\begin{array}{l}\text { I don't want to watch } \\
\text { this again because it was } \\
\text { too monotonous }\end{array}$ & $\begin{array}{l}\text { Too many mistakes and } \\
\text { excessive Japanese; voice } \\
\text { was too quiet }\end{array}$ \\
\hline
\end{tabular}




Appendix B
Writing Evaluation Rubric
\begin{tabular}{|l|l|l|l|}
\hline Score & Content & $\begin{array}{l}\text { The number of words in } \\
\text { the essay }\end{array}$ & $\begin{array}{l}\text { The number of } \\
\text { grammatical mistakes or } \\
\text { wrong word choices }\end{array}$ \\
\hline 5 & $\begin{array}{l}\text { Informative, clear, and } \\
\text { easy to understand }\end{array}$ & More than 40 words & Fewer than 5 \\
\hline 3 & $\begin{array}{l}\text { Not enough information } \\
\text { to understand the } \\
\text { writer's intention }\end{array}$ & 16 to 39 & 6 to 10 \\
\hline 1 & $\begin{array}{l}\text { Readers had too } \\
\text { many difficulties with } \\
\text { understanding }\end{array}$ & 1 to 15 & More than 10 \\
\hline
\end{tabular}

